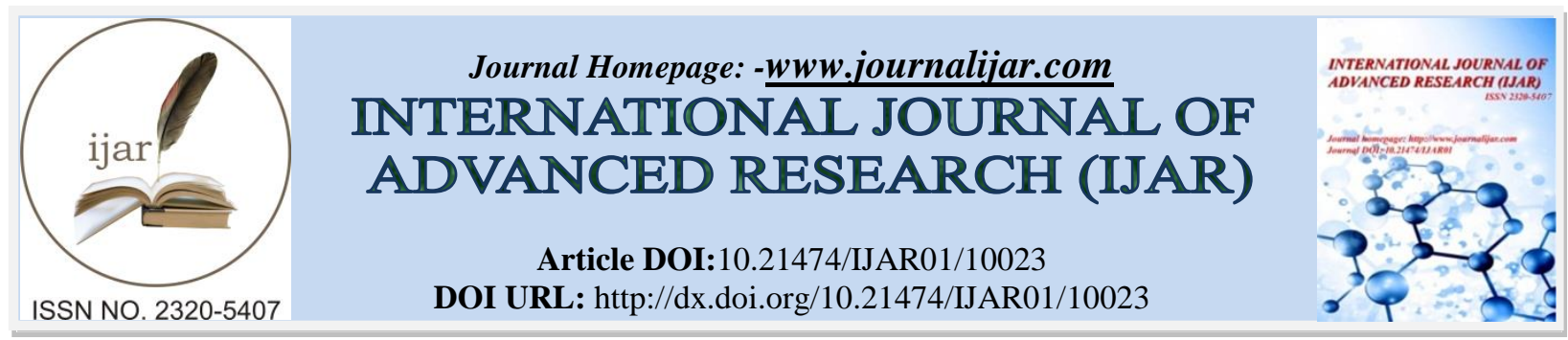

RESEARCH ARTICLE

\title{
ICP/AAS ANALYSIS OF HAIR SAMPLES OF MINERS IN INDISCRIMINATE MINING AREA OF GOLD IN ABU HAMMED CITY, SUDAN.
}

\section{M.Ismail ${ }^{1}$, Elamin.E.Elamin ${ }^{1}$ and A. S. Elhag ${ }^{2}$.}

1. Chemistry Department ,Faculty of Science,University of Khartoum.

2. Sudan Atomic Energy Commission.

\section{Manuscript Info}

Manuscript History

Received: 10 September 2019

Final Accepted: 12 October 2019

Published: November 2019

Key words:-

Hair, Indiscriminate mining, heavy metals, ICP, AAS.

\section{Abstract}

In present study, human head hair samples were collected from River Nile State, Abu-hamad locality. The sampling area was divided in two locations with 30 samples were taken from Washer's (location one) and Evaporator's (location two).

Inductively Coupled Plasma (ICP) was used to identify these elements $(\mathrm{Ni}, \mathrm{Cu}, \mathrm{Pb}$ and $\mathrm{As}$ ) and Atomic Absorption Spectroscopy (AAS) used to determine the elements $(\mathrm{Cu}, \mathrm{Cd}$ and $\mathrm{Pb})$ in human hair samples.

The mean elemental concentration of $\mathrm{Ni}, \mathrm{Cu}, \mathrm{As}$ and $\mathrm{Pb}$ in location one by ICP were $0.13,0.10,0.21$ and $0.23 \mathrm{ppm}$ while the mean elemental concentrations in location two were $0.14,0.09,0.23$ and $0.30 \mathrm{ppm}$ respectively. The mean elemental concentration of $\mathrm{Cu}, \mathrm{Cd}$ and $\mathrm{Pb}$ in location 1 by AAS were 0.038, < LOD, < LOD ppm and 0.012 ppm while the mean elemental concentrations in location 2 were 0.027 , $0.024,0.069 \mathrm{ppm}$ and $0.048 \mathrm{ppm}$ respectively.

The obtained results show that the lowest concentration values of elements were found in Location $\left(\operatorname{Loc}_{1}\right)$ compared to elemental concentration found in Location $\left(\mathrm{Loc}_{2}\right)$. The correlation for the various elements was determined. Also clusters analysis was performed. The enrichment factor (EF) of elements was calculated using $\mathrm{Fe}$ as a reference element. Comparisons between this study and data from literature were done.

\section{Introduction:-}

Determination of trace elements in human hair is important in biological, medical, environmental and forensic science, as it represents an interesting biological matrix for the studies in both, the inorganic and organic field $^{(1)}$. Occupational exposure to metals increases the body burden and subsequently health hazards. Excess concentration of metals causes such as kidney damage, gastrointestinal disturbance, renal failure, dermatitis, respiratory disorder and lung cancer.

Heavy metal pollution and the resulting effects represent a challenge currently facing developing countries, Sudan included. This is reinforced by the fact that metal poisoning is difficult and expensive to assess in developing countries due to the limited resources. Hence there is need to increase the level of understanding and assessment of environmental risk exposure to heavy metal pollution in Sudan. 
The metals may enter the human body through food, air, water and absorption through the skin. Industrial exposure accounts for common route of exposure in adults while ingestion is the common route of exposure in children.

Using hair as a way to detect trace metal exposure is appealing because it is easily and non-invasively sampled, transported, handled, and analyzed ${ }^{(2)}$.The World Health Organization (WHO), Environmental Protection Agency (EPA), and International Atomic Energy Agency (IAEA) have recommended the use of hair as an important biological material for worldwide environmental monitoring ${ }^{(3)}$.

Many analytical techniques such as Atomic Absorption Spectrometry (AAS), Inductively Coupled Plasma Atomic Emission Spectrometry (ICP-AES), X-ray Fluorescence, Neutron Activation Analysis (NAA) and Proton Induced X-ray Emission (PIXE) and Energy Dispersive X-ray Fluorescence (EDXRF) techniques have been widely used for analysis of heavy metals in human hair due to its high sensitivity, low detection limit. The objectives of this study are to measure the levels of $\mathrm{Cu}, \mathrm{Cd}, \mathrm{Ni}, \mathrm{Pb}$ and $\mathrm{As}$ in human hair among indiscriminate mining of gold workers in $\mathrm{Abu}$ hammed city as bio indicator, to identify percentageof $\mathrm{Cu}, \mathrm{Pb}, \mathrm{Ni}, \mathrm{Cd}$ and $\mathrm{As}$ and compare the elemental concentrations obtained with data from literature.

\section{Materials and Methods:- Sampling}

The research has covered 30 people who Indiscriminate mining of gold workers, the sample collected by stainless scissor. The age of subjects range from 21-30 to 51-60 years. Length varies between 3 and 5 cm 0.5-2.0g of hair samples were collected in polyethylene bags, which will be thoroughly closed and labeled. A participants were randomly selected using the lottery method with replacement at the time of data collection and consented to the study, after the purpose of the study have been explained to them.

\section{Samples preparation}

The washing procedure was carried out as per the recommendation of international atomic energy agency (IAEA).Hair samples 100mg were weighing near the scalp following the sequence acetone - deionized water deionized water - deionized water - acetone. Washed samples were oven-dried at $608 \mathrm{C}$ for $24 \mathrm{~h}$ and then weighed. For wet ashing, $2 \mathrm{ml}$ of $\mathrm{HNO}_{3}(65 \%$ nitric acid) were added to each sample, in graduated tubes. Tubes were screw capped and the acid was allowed to react in a sand bath at approximately $60{ }^{\circ} \mathrm{C}$. Samples were allowed to cool and dropwise addition of $1 \mathrm{ml}$ aliquots of $\mathrm{H}_{2} \mathrm{O}_{2}$ was made until a clear solution was obtained. Samples were diluted to a final volume using deionized water. Sample blanks were prepared following the same procedure .The samples are ready for ICP and AAS measurement.

\section{ICP and AAS measurements}

The concentrations $\mathrm{Cu}, \mathrm{Pb}, \mathrm{Ni}, \mathrm{Cd}$ and $\mathrm{As}$, were determined by inductively coupled plasma atomic emission spectrometry and flame atomic absorption spectrometry . Considering the importance of quality assurance, a parallel routine check of the accuracy and precision of quantified results was ensured.

\section{Results and Discussion:-}

Elemental concentrations in human hair samples:

The average concentrations of $\mathrm{Cu}, \mathrm{Cd}, \mathrm{Pb}, \mathrm{Ni}$ and $\mathrm{As}$ is quantified using ICP and AAS techniques in hair samples of miners in Abu hamed indiscriminate mining areas in different locations (Loc 1 \& Loc 2) and their standard deviation are presented in Table $1 \& 2$, respectively. However, the average concentrations of all elements in hair samples location 2 were significantly higher than those hair samples form location one.

Hair samples are good indicators for certain toxic elements, when using hair samples, the external contamination is the main problem. In spite of the external contamination and lack of standardized methodology, the World Health Organization (WHO), Environmental Protection Agency (EPA), and International Atomic Energy Agency (IAEA) have recommended the use of hair as an important biological material for worldwide environmental monitoring.

The elemental concentration (ppm) of these elements $(\mathrm{Cu}, \mathrm{Cd}, \mathrm{Pb}, \mathrm{Ni}$ and $\mathrm{AS}$ ) in human hair by ICP and AAS samples from different locations are presented in Table $(3 \& 4)$, respectively.ICP results shows that the concentration of $\mathrm{Cu}$ in location one ranges between $0.07-0.13 \mathrm{ppm}$ with an average value of $0.12 \mathrm{ppm}$. $\mathrm{Pb}$ concentration ranges between $0.12-0.36 \mathrm{ppm}$ with an average value of $0.20 \mathrm{ppm}$. The concentration of Ni ranges between $0.07-0.20 \mathrm{ppm}$ with average value of $0.10 \mathrm{ppm}$. As concentration ranges between $0.10-0.33 \mathrm{ppm}$ with an 
average value of $0.22 \mathrm{ppm}$. In location two, the concentration of $\mathrm{Cu}$ in location one ranges between $0.006-0.23 \mathrm{ppm}$ with an average value of $0.14 \mathrm{ppm}$. Pb concentration ranges between $0.02-0.92 \mathrm{ppm}$ with an average value of 0.23 ppm. The concentration of $\mathrm{Ni}$ ranges between $0.01-0.40 \mathrm{ppm}$ with average value of 0.09 ppm. As concentration ranges between $0.02-0.70 \mathrm{ppm}$ with an average value of $0.30 \mathrm{ppm}$. The AAS results, in location one, the concentration of copper ranges between 0.003 and $0.113 \mathrm{ppm}$ with mean value of $0.038 \mathrm{ppm}$. Hh $\mathrm{H}_{13}$ sample showed the highest concentration while $\mathrm{Hh}_{110}$ and $\mathrm{Hh}_{111}$ samples showed the lowest value. Cadmium concentration was less than detection limits in all the analyzed samples in this location, except the sample $\mathrm{Hh}_{14}$. The concentration of lead is less than detection limits in all samples in location one. Nickel concentration ranges between $0.013 \mathrm{ppm}$ and 0.136 ppm with mean value of $0.053 \mathrm{ppm}$. $\mathrm{Hh}_{18}$ recorded the highest concentration value, while $\mathrm{Hh}_{13}$ sample recorded the lowest value. The concentration of copper in location two ranges between $0.016 \mathrm{ppm}$ and $0.049 \mathrm{ppm}$ with mean value of $0.027 \mathrm{ppm}$. $\mathrm{Hh}_{210}$ sample showed the highest concentration while $\mathrm{Hh}_{214}$ sample showed the lowest value.

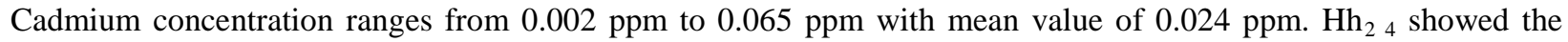
highest concentration while $\mathrm{Hh}_{110}$ showed the lowest value. The concentration of Lead ranges from $0.025 \mathrm{ppm}$ and $0.298 \mathrm{ppm}$ with mean value of $0.069 \mathrm{ppm}$. $\mathrm{Hh}_{22}$ recorded the highest concentration value, while the samples $\mathrm{Hh}_{113}$ recorded the lowest values. Nickel concentration ranges between $0.020 \mathrm{ppm}$ and 0.062 ppm with mean value of $0.040 \mathrm{ppm}$ and standard deviation $0.012 \mathrm{ppm}$. $\mathrm{Hh}_{15}$ recorded the highest concentration value, while Hh 11 sample recorded the lowest value. In location one, the elements follows this order $\mathrm{Cd}>\mathrm{Pb}>\mathrm{Cu}>\mathrm{Ni}$, while in location two following this order $\mathrm{Cd}>\mathrm{Cu}>\mathrm{Ni}>\mathrm{Pb}$. The results of elements analyses indicated that $\mathrm{Pb}$ is higher in location two compared to its value which measured in location one. Nickel concentration is higher in location one than it's concentration in location two.

\section{Correlation Analysis}

Table 5 \& 6 summarizes the correlation between the elemental concentrations data for human hair samples in location 1 \& 2 respectively. The coefficient between $\mathrm{Ni}-\mathrm{As}, \mathrm{Ni}-\mathrm{Pb}$ and $\mathrm{As}-\mathrm{Pb}$ was positive and statistically significant in location one, while also the coefficient between $\mathrm{Ni}-\mathrm{Cu}, \mathrm{Ni}-\mathrm{As}, \mathrm{Ni}-\mathrm{Pb}, \mathrm{Cu}-\mathrm{As}, \mathrm{Cu}-\mathrm{Pb}$ and $\mathrm{As}-\mathrm{Pb}$ was positive and statistically significant in location two. These correlations may be due to the natural geochemical background. The same correlations were found in Loc1 \& Loc 2, but in Loc2 was found an extra correlation of Cu with these elements $\mathrm{Ni}, \mathrm{Cu}$ and $\mathrm{Pb}$ it may be due to the high temperature of consummation process in gold mining. It has been reported that several factors such as gender, age and geographic location affect heavy metals levels in human hair.

\section{Cluster Analysis}

The cluster analysis was applied using the SPSS package for the data obtained. Fig (2) shows the Cluster grouping of elements in human hair samples. The clustering procedure generated three groups of samples. The cluster 1 includes $\mathrm{Cu}$ and $\mathrm{Pb}$ which reflects the similarity in the concentration in human hair samples. Cluster 2 includes Cd and $\mathrm{Ni}$ and Cluster 3 includes only As which enriched in sample may due to combustion of ore in mining activity.

\section{Enrichment factor (EF):}

Table 7shows concentration of the elements compared to crustal abundances from Mason (40). The enrichment factor (EF) is the enrichment of the element in hair compared to that in Earth's crust, using Fe as a reference element. An enrichment of unity indicates a soil-derived element, whereas elements derived from high temperature combustion processes will be more volatile and haveenrichment factors significantly above one. EF calculation showed that $\mathrm{Cu}$ and $\mathrm{Ni}$ is significant enriched, while the other elements $\mathrm{Cd}, \mathrm{As}$ and $\mathrm{Pb}$ is extremely high enriched.

Comparison of elemental concentration between this Study and data from literature ${ }^{(4-10)}$ :

Table 8 shows the comparison of elemental concentration between this study and data from literature. Generally, the average concentrations of $\mathrm{Pb}$ were higher in Kenya and Libya than the values in India, Egypt, Poland, Nigeria, China and this study. Cd concentrations in India, Egypt, Poland, Libya and this study are less than the concentration in Kenya, Portugal. Nigeria and China. The concentration of $\mathrm{Cu}$ in Kenya. Poland, China. India, Egypt and Portugal is higher compared to Nigeria and this study. 
Table 1:-The average elemental concentrations $(\mathrm{ppm}) \pm \mathrm{SD}$ of analyzed elements in hair samples using ICP in different locations

\begin{tabular}{|l|l|l|l|l|l|}
\hline & $\begin{array}{l}\text { Number } \\
\text { samples }\end{array}$ & $\mathrm{Cu}$ & $\mathrm{Pb}$ & $\mathrm{Ni}$ & $\mathrm{As}$ \\
\hline Loc 1 & 11 & $0.12 \pm 0.05$ & $0.20 \pm 0.08$ & $0.10 \pm 0.03$ & $0.22 \pm 0.09$ \\
\hline Loc 2 & 15 & $0.14 \pm 0.14$ & $0.23 \pm 0.25$ & $0.09 \pm 0.08$ & $0.30 \pm 0.34$ \\
\hline
\end{tabular}

Table 2:-The average elemental concentrations $(\mathrm{ppm}) \pm \mathrm{SD}$ of analyzed elements in hair samples using AAS in different locations

\begin{tabular}{|l|l|l|l|l|}
\hline & Number of samples & $\mathrm{Cu}$ & $\mathrm{Pb}$ & $\mathrm{Cd}$ \\
\hline Loc 1 & 11 & $0.04 \pm 0.05$ & $<\mathrm{LOD}$ & $<\mathrm{LOD}$ \\
\hline Loc 2 & 15 & $0.03 \pm 0.01$ & $0.07 \pm 0.07$ & $0.02 \pm 0.03$ \\
\hline
\end{tabular}

Table 3:-Summary of statistical data for elemental concentrations $(\mathrm{ppm})$ in hair samples in different locations using ICP

\begin{tabular}{|l|l|l|l|l|l|}
\hline Location & N of samples & elements & Min & Max & Mean \\
\hline Loc1 & 11 & $\mathrm{Cu}$ & 0.07 & 0.13 & 0.12 \\
\hline & & $\mathrm{Pb}$ & 0.12 & 0.36 & 0.20 \\
\hline & & $\mathrm{Ni}$ & 0.07 & 0.20 & 0.10 \\
\hline & & $\mathrm{AS}$ & 0.10 & 0.33 & 0.22 \\
\hline Loc2 & $\mathrm{Cu}$ & 0.006 & 0.23 & 0.14 \\
\hline & 15 & $\mathrm{~Pb}$ & 0.02 & 0.92 & 0.23 \\
\hline & & $\mathrm{Ni}$ & 0.01 & 0.40 & 0.09 \\
\hline & & $\mathrm{As}$ & 0.02 & 0.70 & 0.30 \\
\hline & & & &
\end{tabular}

Table 4:-Summary of statistical data for elemental concentrations (ppm) in hair samples in different locations using AAS

\begin{tabular}{|l|l|l|l|l|l|}
\hline Location & N of samples & elements & Min & Max & Mean \\
\hline Loc1 & 11 & $\mathrm{Cu}$ & $<$ LOD & 0.11 & 0.04 \\
\hline & & $\mathrm{Pb}$ & $<$ LOD & $<$ LOD & $<$ LOD \\
\hline & & $\mathrm{Cd}$ & $<$ LOD & 0.06 & $<$ LOD \\
\hline Loc2 & 15 & $\mathrm{Cu}$ & $<$ LOD & 0.05 & 0.03 \\
\hline & & $\mathrm{Pb}$ & 0.03 & 0.30 & 0.07 \\
\hline & & $\mathrm{Cd}$ & $<$ LOD & 0.07 & 0.02 \\
\hline
\end{tabular}

Table 5:-Correlation between the elemental concentrations data for human hair samples in location 1

\begin{tabular}{|l|l|l|l|l|l|}
\hline & $\mathrm{Ni}$ & $\mathrm{Cu}$ & $\mathrm{As}$ & $\mathrm{Pb}$ & \\
\hline $\mathrm{Ni}$ & 1 & & & & \\
\hline $\mathrm{Cu}$ & 0.615 & 1 & & & \\
\hline $\mathrm{As}$ & $\mathbf{0 . 9 8 7}$ & 0.438 & 1 & 1 & \\
\hline $\mathrm{Pb}$ & $\mathbf{0 . 9 9 6}$ & 0.542 & $\mathbf{0 . 9 9 7}$ & $* * *$ & \\
\hline $\mathrm{Cd}$ & $* * *$ & $* * *$ & $* * *$ & 1 \\
\hline
\end{tabular}

Table6:-Correlation between the elemental concentrations data for human hair samples in location 2

\begin{tabular}{|l|l|l|l|l|l|}
\hline & $\mathrm{Ni}$ & $\mathrm{Cu}$ & $\mathrm{As}$ & $\mathrm{Pb}$ & $\mathrm{Cd}$ \\
\hline $\mathrm{Ni}$ & 1 & & & & \\
\hline $\mathrm{Cu}$ & $\mathbf{0 . 9 9 8}$ & 1 & & & \\
\hline $\mathrm{As}$ & $\mathbf{0 . 9 9 9}$ & $\mathbf{0 . 9 9 6}$ & 1 & 1 & \\
\hline $\mathrm{Pb}$ & $\mathbf{0 . 9 9 7}$ & $\mathbf{0 . 9 9 3}$ & $\mathbf{0 . 9 9 9}$ & -0.077 & 1 \\
\hline $\mathrm{Cd}$ & -0.082 & -0.041 & -0.099 & & \\
\hline
\end{tabular}




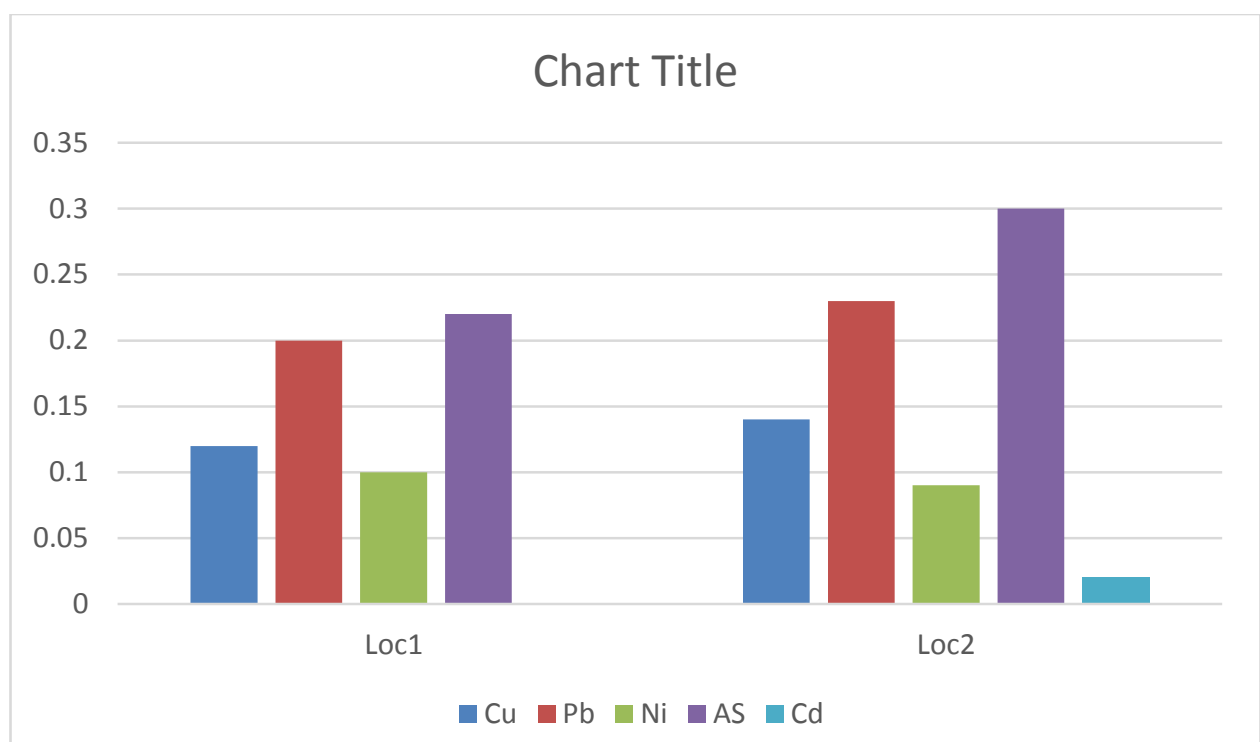

Fig 1:-Mean elemental concentrations (ppm) of $\mathrm{Cu}, \mathrm{Pb}$. $\mathrm{Ni}, \mathrm{As}$ and $\mathrm{Cd}$ in hair samples in different locations Dendrogram using Average Linkage (Between Groups)

Rescaled Distance Cluster Combine

$\begin{array}{lllllll}\text { C A S E } & 0 & 5 & 10 & 15 & 20 & 25\end{array}$

Label Num +---------+---------+---------+---------+---------+

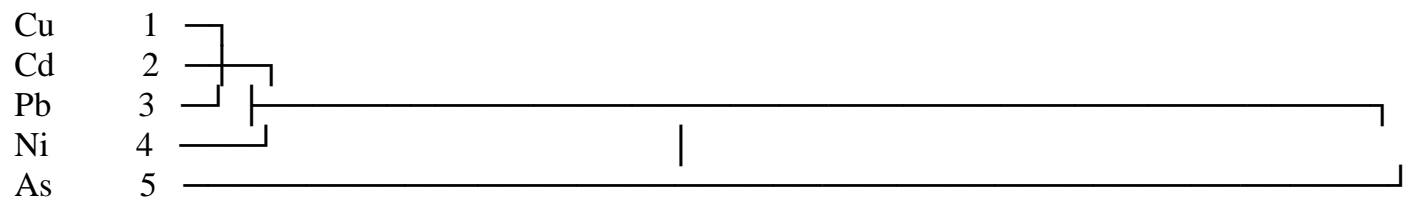

Fig 2:-Cluster analysis

Table 7:-Enrichment factor for analyzed elements:

\begin{tabular}{|l|l|}
\hline Element & $\mathrm{EF}$ \\
\hline $\mathrm{Cu}$ & 8.07 \\
\hline $\mathrm{Ni}$ & 10.18 \\
\hline $\mathrm{Cd}$ & $>40$ \\
\hline $\mathrm{As}$ & $>40$ \\
\hline $\mathrm{Pb}$ & $>40$ \\
\hline
\end{tabular}

Table 8:-Comparison of elemental concentration between this Study and data from literature:

\begin{tabular}{|l|l|l|l|l|l|}
\hline Country & $\mathrm{Pb}$ & $\mathrm{Cd}$ & $\mathrm{Cu}$ & $\mathrm{Ni}$ & $\mathrm{As}$ \\
\hline Egypt & 5.95 & 0.44 & 10.6 & - & \\
\hline Kenya & 52 & 2.22 & 24 & - & \\
\hline Portugal & - & $0.17-1.52$ & $7.7-27.2$ & - & \\
\hline China & 1.62 & 0.9 & 12 & 0.94 & 0.18 \\
\hline India & 8.03 & 0.4 & 14.7 & - & \\
\hline Poland & 4.8 & 0.55 & 7.2 & - & \\
\hline Nigeria $(\mu \mathrm{g} / \mathrm{g})$ & 65.4 & 1.2 & 117.2 & 26.4 & - \\
\hline Libya & 24.95 & 0.53 & - & - & \\
\hline This Study & 0.6 & 0.02 & 0.12 & 0.13 & 0.44 \\
\hline
\end{tabular}




\section{Conclusion:-}

In this study, heavy metals $(\mathrm{Cu}, \mathrm{Pb}, \mathrm{Ni}, \mathrm{Cd}$ and $\mathrm{As})$ were determinedin human hair samples using Inductively Coupled Plasma (ICP) and Atomic Absorption Spectrometry (AAS) techniques. The results showed that samples from location one has the lowest concentrations values compared to samples from location two. The mean elemental concentrations of all elements analyzed in this study were less than data from literature.

\section{Recommendations:}

1. Awareness of dangers of toxic elements especially miners.

2. Flow an occupational safety rules in traditional mining.

3. New studies may nesessate more sampling with comparative groups and modern instrumental analysis for new locations to achieve good results and good indication for protecting the human and environment.

\section{References:-}

1. Wang S, Shi X (2001) Molecular mechanisms of metal toxicity and carcinogenesis. Mol Cell Biochem 222:3-9.

2. Stern BR (2010) Essentiality and toxicity in copper health risk assessment: overview, update and regulatory considerations. Toxicol Environ Health A 73:114-127

3. Harvey LJ, McArdle HJ (2008) Biomarkers of copper status: a brief update. Br J Nutr 99:S10-S13 18. ATSDR (2002) Toxicological profile for copper. Centers for Disease Control, agency for toxic substances and disease registry, Atlanta, GA,p 78-85.

4. Pereira, R., Ribeir, R. and Goncalves, F. (2004). Scalp Hair Analysis as a Tool of Assessing Exposure to Heavy Metals (S. Domingos mine, Portugal). Science of the Total Environment. 327: 81 - 92.

5. Rashed, M. N. and Hossam, F. (2007). Heavy Metals in Finger Nails and Scalp Hair of Children, Adults and Workers from Environmentally Exposed Areas at Aswan, Egypt, Environmental Bioindicators 2 (3): 131-145.

6. Wandiga, S. O. and Jumba, I. O. (1982). The Concentration of Heavy Metals: Zinc, Cadmium, Lead, Copper, Mercury, Iron and Calcium in Head Hair of a Randomly Selected Sample of Kenyan People. Kenya Journal of Science and Technology (A) 3: $27-41$.

7. Luo, R., Zhuo, X., \& Ma, D. (2014). Determination of 33 elements in scalp hair samples from inhabitants of a mountain village of Tonglu city, China. Ecotoxicology and environmental safety, 104, 215-219.

8. Samanta, F. J., Ramesh, S., Tarit, R. and Dipankar, C. (2004). Arsenic and Other Elements in Hair, Nails and Skin Scales of Arsenic Victims in West Bangal, India. Science of the Total Environment, 326: $33-47$.

9. Nowak, B. and Chmielnicka, J. (2000). Relationship of Lead and Cadmium to Essential Elements in Hair, Teeth and Nails of Environmentally Exposed People. Ecotoxicology and Environmental Safety. 46: 265 274

10. Adekola, F. A., Dosumu, O. O. and Olaleye, G. A. (2004). Comparative study of the Age and Location Dependence of Some Heavy Metals in Human Hair from Two Nigerian Cities. Toxicol and Environ Chem, 86(4): 191 - 196. 